\title{
Economic Administration and Institutional Management in a Decentralized Regime Mode: New Insights from Environmental Resources
}

\author{
Submitted 21/08/19, $1^{\text {st }}$ revision 13/09/19, $2^{\text {nd }}$ revision 20/10/19 accepted 20/11/19
}

\author{
Andriansyah Andriansyah ${ }^{1}$, Endang Sulastri ${ }^{2}$, Evi Satispi ${ }^{3}$
}

\begin{abstract}
:
Purpose: There are many factors causing deterioration of environmental quality and environmental damage that can be identified from observations in the field. Therefore in this paper we try to be revealed in general as a picture of environmental portraits, especially in relation to environmental management and enforcement of environmental law in the era of regional autonomy.

Design/methodology/approach: By using qualitative method, the study was conducted in about six months (February to August of 2018) in West Java Province to observe Indonesian government's policy on environmental law in the era of regional autonomy.

Findings: The results found that the decentralization system made environmental policy making and implementation overlapping and not uniform both horizontally and vertically. This management is also not supported by adequate management institutions, so that environmental management has not yet had a positive economic effect on the people.

Practical implications: Although public understanding and awareness of the importance of the environment has been increased some people are still weak and must to be improved on this issue. The study can be used as an example to achieve this goal quite effectively.

Originality/value: The study seeks to examine public administration of natural resources and management of environmental institutionalization in a state by adopting a decentralized system, which takes Indonesia as a case study using a special region in West Java Province.
\end{abstract}

Keywords: Economic administration, institutional management, decentralized system, environmental resources.

JEL code: G34.

Paper type: Research article.

\footnotetext{
${ }^{1}$ Corresponding author, Faculty of Social and Political Sciences, Universitas Prof Dr Moestopo (Beragama), Indonesia, e-mail: andriansyahmoestopo@gmail.com

${ }^{2}$ Faculty of Social and Political Sciences, Universitas Muhammadiyah, Jakarta, Indonesia, email: endangsulastri_es@yahoo.com

${ }^{3}$ Faculty of Social and Political Sciences, Universitas Muhammadiyah Jakarta, Indonesia, email: evis.satispi@umj.ac.id
} 


\section{Introduction}

Development in various developing countries that adopt a decentralized system at the sub-national level has been widely criticized for lacking the principle of sustainable development (Dupar and Badenoch, 2002; Clement, 2010). Development carried out often causes damage to the ecosystem environment. The regional authority to provide industrial business licenses and mineral resource mining seems to be ignored by businesses to maintain environmental sustainability (Tacconi, 2007; Larson, 2012). In Indonesia, every activity in development that is in contact with the environment requires Environmental Quality Standards. Article 15 of Law 4 of 1982 concerning Basic Provisions for Environmental Management which stipulates that Environmental Quality Standards are regulated by legislation. As such, Environmental Quality Standards are an important instrument in environmental management (Mardiya, 2018).

The existence of activities or production activities that are not in accordance with the existing Environmental Quality Standards, means that there has been a violation of the applicable legal provisions. At a certain level, if there is environmental pollution, it can be clarified as a crime against the environment. This can be processed legally to court. The desire of the community through environmental NGOs or individuals who are informed through the mass media to bring environmental criminals to court, increasingly gives reasons that perpetrators of crimes against the environment must be deterred, so that they are processed according to existing legal provisions.

In essence, a decentralized area has the authority and obligation to organize a broader, real and responsible local government (Lisdiyono, 2018). The balance of duties and functions between the central government and the regional government has caused each region to have sufficient income, the region must have adequate funding sources to assume the responsibility for implementing regional government. Thus, it is expected that each region will be able to be more advanced, independent, prosperous and competitive in the implementation of government and regional development. The authority granted by the central government in the form of regional autonomy does not seem to have been properly interpreted, many regions are obsessed with economic growth and development, leaving the environment damaged where this clearly violates the Law No. 32 of 2009 concerning Environmental Protection and Management. Violations of the law are clearly not in accordance with the initial objectives of regional autonomy. Apart from that, environmental damage due to massive exploitation of natural resources has become a serious problem in the region. Protection and management of the environment is a systematic and integrated effort carried out to preserve environmental functions and prevent pollution and/or environmental damage which includes planning, utilization, control, maintenance, supervision and law enforcement. In section 63 paragraph 1c$3 \mathrm{c}$ it is stated that the central government to the regions has the authority and duty to establish and implement policies in accordance with environmental management and protection plans. Besides that in Law article 65 paragraph 2 and in article 70, it is 
explained about the need to involve the participation of the community in the management and protection of the environment both passively and actively. This study seeks to examine public administration of natural resources and management of environmental institutionalization in a state mode with a decentralized system, which generally takes Indonesia as its case study.

\section{Research Methodology}

The study used qualitative method with descriptive research design. The authors use the type of descriptive research, because according to the authors this approach method is very appropriate in designing and gathering information on real conditions. Qualitative research according to Miles and Huberman (1992) is one of the research procedures produced by descriptive data in the form of speech or writing and the behavior of people who are observed in the field through primary and secondary data through decommentation studies. The authors take qualitative research, because it can recognize subjects and feel what they experience in everyday life from informants.

The main purpose in using qualitative research methods is to describe the nature of a situation that is currently running at the time the research was conducted, and examine the causal factors for a particular symptom (Bernard and Bernard, 2013). The study was conducted in about six months, from February to August of 2018, in West Java Province on the problems presented above. That is the Indonesian government's policy on environmental law in the era of regional autonomy, whereas the informants interviewed for the research were determined before going to the field. Informants are people who are considered to know or possess high knowledge of the problems of government policy on environmental law in the era of regional autonomy. Informants are divided into two, namely primary informant and technical informants, classes where the primary informants in this study are policy makers in related ministries or institutions and technical informants those who know and can evaluate the problem.

\section{Decentralized Mode: An Urgency of Environmental Public Policy}

Decentralization was commonly interpreted as the transfer of responsibility, authority, and resources (funds, people, etc.) from the central government to local governments (Larson, 2002; Crook, 2003). The underlying rationale is the desire to transfer decision making closer to those who feel first the influence of programs and services designed and implemented by the government. This will increase the relevance between public services and the needs and conditions of local communities, while at the same time pursuing the objectives of the government at the regional and national levels, from a social and economic perspective (Azfar et al., 1999). Initiatives to improve planning, implementation and finance of socioeconomic development are expected to guarantee the use of government resources effectively and efficiently to meet local needs (Firman, 2009). 
A similar view was also expressed by Rondinelli and Cheema (1983) who have detailed 14 advantages of decentralization and regional autonomy policies, six of which are making articulation and implementation of development policies, reducing and simplifying complicated procedures, implementing coordination of various activities more effectively, increasing efficiency if handled by regional officials, increasing community participation in development and providing services by the government to the community regarding basic needs that will be much more efficient.

The Indonesian Government's policy in providing regional autonomy is to provide the division and delegation of power from the central government to regional governments to manage their regions in accordance with their potential (Firman, 2009). Based on Law No. 25 of 2004 concerning the National Development Planning System, it is explained that in order to promote development evenly there are needs to be satisfied leading to decentralized development. This is to realize the implementation of decentralization in the era of regional autonomy. Decentralization of regional development can be realized in the Regional Long-Term Development Plan, for the next 25 years; Regional Medium Term Development Plan, which is for the next 5 years; Regional Government Work Plan, which is for the subsequent year and Strategic Planning for Regional Development to increase economic growth and development in the region.

Therefore, the area to utilize the regional autonomy is to develop and climb the area in accordance with the potential of the region they have. Implementation of regional autonomy has entered a new era after the government and the Indonesian House of Representatives have agreed to ratify Law No. 32 Year 2004, concerning Regional Government and Law No. 33 Year 2004, concerning Financial Balance between Central and Regional Governments. Both of these regional autonomy laws are revisions to Law No. 22 and No. 25 of 1999 so that the two laws are no longer valid. More than a decade regional autonomy has been implemented but in fact there are still many problems in the region, there are even indications of violations of other regulations in the name of developing regional autonomy and development. The initial goal of regional autonomy is to improve regional economic growth and equitable development between the center and the regions (Rodríguez-Pose and Ezcurra, 2009). This goal seems to be the motivation of the region to exploit the potential of its own resources, such as the example of natural resources. Many in the region have abundant natural resources in terms of mining mineral resources, metals and others exploited by the local government on the grounds to increase the income of regional own-source revenue, economic growth, development, poverty alleviation, and community welfare (Suratno and Soerjo, 2018).

\section{Strengthening Environmental Management and Institutions}

The weak side that stands out in implementing environmental legislation is law enforcement. With the rapid national development carried out which aims to 
improve the welfare of the community, there are some weak sides, among others, those that are not matched by the obedience of rules by development actors or often ignore the regulatory basis that should be used as guidance in carrying out and managing business and/or activities social and environmental issues, causing environmental problems (Hyden and Hydén, 1983). Therefore, in accordance with the plan for Sustainable Development in the Protection and Management of the Environment carried out to improve the quality of the environment through efforts to develop legal systems, legal instruments, compliance and law enforcement including alternative instruments, as well as environmental rehabilitation efforts need to be established (Aronson et al., 2011).

Regional policies in addressing environmental problems, especially policy and law enforcement issues, which are one of the environmental problems in the region, may include: (a) regional regulations on the environment through strengthening environmental institutions; (b) application of environmental management documents in the licensing process; (c) dissemination/education about legislation and environmental knowledge; (d) improve the quality and quantity of coordination with relevant agencies and stakeholders; (d) integrated supervision of environmental law enforcement; (e) formulate forms and types of sanctions for environmental violations; (f) increasing the quality and quantity of human resources; $(\mathrm{g})$ increasing funding in environmental management; (h) environmental management is an integrated effort to preserve environmental functions which include policies on the arrangement, utilization, development, maintenance, recovery, supervision and control of the environment; (i) what is meant by the environment is the unity of space with all objects, power, conditions and living things including humans and their behavior which affects the survival of life and the welfare of humans and other living beings.

Declining environmental conditions is also caused by decision making (Scyphers $e t$ al., 2015), in which the importance of conservation is often overlooked resulting in pollution and environmental damage. With the occurrence of pollution and environmental damage it also causes social conflicts and environmental conflicts (Cáceres, 2015). With these various problems, legal instruments for environmental protection are needed, in general it has been regulated in Indonesia by Law No. 4 of 1982. However, based on experience in implementing various provisions regarding law enforcement as stated in the Environmental Law, then in the Management Law Environmental changes have been made to facilitate the application of provisions relating to the enforcement of environmental law, namely Law No. 4 of 1982, replaced by Law No. 23 of 1997, concerning Environmental Management and then further regulated in its implementing regulations. This law is one powerful tool in protecting the environment. In its application, it is supported by sectoral laws and regulations. This is because Environmental Management requires coordination and integration in a sectoral manner carried out by non-departmental government departments and institutions in accordance with their respective fields of duties and responsibilities, such as Law No. 22 of 2001 concerning Gas and Earth, Law No. 41 
of 1999 concerning Forestry, Law No. 24 of 1992 concerning Spatial Planning and to be followed by further regulation by the Government, Presidential Decrees, Ministerial Decrees, Regional Regulations and Governor Decrees.

\section{Regional Environment in a Decentralized Mode}

Considering the complexity of environmental management and problems that are cross-sectoral and regional in nature, the implementation of development requires planning and implementation of environmental management in line with the principles of sustainable development namely economic development, sociocultural, balanced living environment as interdependent pillars. In its implementation, it involves various parties, as well as assertiveness in compliance with environmental law. It is hoped that with the participation of various parties and the supervision and compliance of laws that can truly be enforced, it can be used as a joint reference to manage the environment in a wise manner so that sustainable development goals can really be implemented in the field (Glaser et al., 2010). Matters relating to environmental management in the region in the era of regional autonomy include some considerations.

First, sectoral and regional ego. Regional autonomy which is expected to be able to provide part of the authority to manage the environment in the regions has not been able to be implemented properly. Regional ego is still often seen in the implementation of environmental management, life, as well as the ego sector. Environmental management is often carried out overlapping between sectors with other sectors.

Second, overlapping planning between sectors. The fact shows that program planning, including environmental management, overlaps between one sector with another.

Third, programs and activities must be supported with adequate funds if they expect good success. Even though everyone acknowledges that the environment is an important and very necessary field, in reality the local own-source revenue is still too low which is allocated for environmental management programs, compounded by the absence of funds from the state budget allocated directly to the regions for environmental management.

Fourth, limited capability of human resources. It must be admitted that in the management of living environments in addition to adequate funds must also be supported by qualified resources. Human resources are often still not supportive. Personnel who are supposed to be in charge of carrying out environmental management, including local government officials, many have not understood well the importance of the environment. 
Fifth, exploitation of natural resources still prioritizes economic profit (Veltmeyer, 2013). Natural resources should be used for development to achieve community welfare. Although the reality is not so, logging and exploitation of mining materials, for instance, benefits some people only, in which the environmental aspects are ignored. Facts show that there is no balance between the economy and the environment. Environmental problems still do not get the proper attention.

Sixth, weak implementation of legislation. The laws and regulations relating to the environment are quite numerous, but the implementation is still weak. There are some parties who actually do not implement the laws and regulations properly, even look for weaknesses of the laws and regulations to be used to achieve their objectives.

Seventh, weak enforcement of environmental law, especially in supervision. Regarding the implementation of laws and regulations is the supervision side of the implementation of laws and regulations. Many violations were committed in environmental pollution, environmental destruction, but were very weak in providing legal sanctions.

Eighth, public understanding and awareness of the importance of the environment, some people are still weak and this, needs to be improved.

\section{Conclusion}

In a mode of regional autonomy, it appears that there is a tendency for increasingly complex environmental problems, which should not be the case. There is a temporary suspicion that the environmental deterioration is related to the implementation of regional autonomy, in which regions want to increase regional own-source revenue by exploiting natural resources that do not pay proper attention to environmental aspects. In this way there is a deterioration in the quality of the environment everywhere, followed by the emergence of natural disasters. There are many things that cause the environmental aspects to be less noticed in the development process, which varies from region to region, from local matters such as the availability of human resources to things of a wider scale such as the application of unfriendly technology environment.

Laws and regulations relating to environmental management are sufficient, however, in their implementation, including the supervision of their implementation needs to get serious attention. This is closely related to the good intentions of the government, including the regional government, the community and the parties concerned to manage the environment in a better way so that the principles of environmentally sustainable development can be carried out well. Because development is basically for the welfare of the community, the aspirations of the community need to be heard and development activities programs really touch the interests of the community. 


\section{References:}

Aronson, J., Brancalion, P.H., Durigan, G., Rodrigues, R.R., Engel, V.L., Tabarelli, M., Torezan, J.M., Gandolfi, S., de Melo, A.C., Kageyama, P.Y. and Marques, M.C. 2011. What role should government regulation play in ecological restoration? Ongoing debate in São Paulo State, Brazil. Restoration Ecology, 19(6), 690-695.

Azfar, O., Kahkonen, S., Lanyi, A., Meagher, P. and Rutherford, D. 1999. Decentralization, governance and public services: The impact of institutional arrangements. Centre for Institutional Reform and the Informal Sector, 1-37.

Bernard, H.R. and Bernard, H.R. 2013. Social research methods: Qualitative and quantitative approaches. Sage.

Cáceres, D.M. 2015. Accumulation by Dispossession and Socio-Environmental Conflicts Caused by the Expansion of Agribusiness in A rgentina. Journal of Agrarian Change, 15(1), 116-147.

Clement, F. 2010. Analysing decentralised natural resource governance: proposition for a "politicised" institutional analysis and development framework. Policy Sciences, 43(2), 129-156.

Crook, R.C. 2003. Decentralisation and poverty reduction in Africa: the politics of localcentral relations. Public Administration and Development: The International Journal of Management Research and Practice, 23(1), 77-88.

Dupar, M.K. and Badenoch, N. 2002. Environment, livelihoods, and local institutions: Decentralization in mainland Southeast Asia. World Resources Inst.

Firman, T. 2009. Decentralization reform and local-government proliferation in Indonesia: Towards a fragmentation of regional development. In Review of Urban \& Regional Development Studies: Journal of the Applied Regional Science Conference, Vol. 21, No. 2-3, 143-157. Melbourne, Australia, Blackwell Publishing Asia.

Glaser, M., Baitoningsih, W., Ferse, S.C., Neil, M. and Deswandi, R. 2010. Whose sustainability? Top-down participation and emergent rules in marine protected area management in Indonesia. Marine Policy, 34(6), 1215-1225.

Hyden, G. and Hydén, G. 1983. No shortcuts to progress: African development management in perspective. University of California Press.

Larson, A.M. 2002. Natural resources and decentralization in Nicaragua: Are local governments up to the job? World Development, 30(1), 17-31.

Larson, A.M. 2012. Democratic decentralization in the forestry sector: lessons learned from Africa, Asia and Latin America. In The politics of decentralization, (46-76). Routledge.

Lisdiyono, E. 2018. Legal Idealism and Implementation: An Analysis of the Gap Between Environmental Policy and the Local Regulation in Indonesia. Journal of Legal, Ethical and Regulatory Issues.

Mardiya, N.Q.A. 2018. The regulation of corporate liability in environmental criminal act. Jurnal Hukum dan Peradilan, 7(3), 483-502.

Miles, M.B. and Huberman, A.M. 1992. Qualitative Data Analysis. CA, Sage.

Rodríguez-Pose, A. and Ezcurra, R. 2009. Does decentralization matter for regional disparities? A cross-country analysis. Journal of Economic Geography, 10(5), 619644.

Rondinelli, D.A. and Cheema, G.S. 1983. Decentralization and development: policy implementation in developing countries. Beverly Hills, Sage. 
Scyphers, S.B., Picou, J.S. and Powers, S.P. 2015. Participatory conservation of coastal habitats: the importance of understanding homeowner decision making to mitigate cascading shoreline degradation. Conservation Letters, 8(1), 41-49.

Suratno, and Soerjo, A.P. 2018. Effect of government investment and capital participation on local own-source revenue: The case of Indonesia. European Research Studies Journal, 21(4), 368-377.

Tacconi, L. 2007. Decentralization, forests and livelihoods: theory and narrative. Global environmental change, 17(3-4), 338-348.

Veltmeyer, H. 2013. The political economy of natural resource extraction: a new model or extractive imperialism? Canadian Journal of Development Studies/Revue canadienne d'études du développement, 34(1), 79-95. 